\title{
How Prehistoric Obstetric Practices Gave Humans Bipedalism and Big Brains: An Evolutionary Anatomical Review
}

\author{
Craig Smith ${ }^{1}$
}

${ }^{1}$ Affiliation not available

May 20, 2020

\begin{abstract}
Their radically large brains and obligate bipedalism set humans apart from the rest of the primates. These features are studied in conjunction with their relationship to obstetric practices found universally in modern humans but hypothesized also to have emerged in Australopithecus. Given the emergence of modern-human obstetric practices as necessary for maternal-and-infant survival during parturition, I hypothesize that birth assistance must in the prehistoric past have become indispensable to the ongoing evolution of bipedalism and a big brain in the human lineage. Beginning at a critical point in our prehistoric past, obstetrics began giving humans both bipedalism and big brains.
\end{abstract}

\section{Hosted file}

Obstetric Practices Gave Humans Bipedalism and Big Brains.docx available at https: //authorea.com/users/324377/articles/452798-how-prehistoric-obstetric-practices-gavehumans-bipedalism-and-big-brains-an-evolutionary-anatomical-review 